DOI: 10.20472/EFC.2020.014.009

\title{
DOMAGOJ KARACIC
}

Faculty of Economics, Josip Juraj Strossmayer University of Osijek, Croatia

\section{DAVID KRMPOTIC}

Department of Finance and Procurement, City of Osijek, Croatia

\section{MARIJA ILES}

Faculty of Economics, Josip Juraj Strossmayer University of Osijek, Croatia

\section{TAX AND OWN REVENUES OF LARGE CITIES IN THE REPUBLIC OF CROATIA}

\begin{abstract}
:
The budget revenues of cities in the last few years have not been constant and are largely dependent on a number of factors such as: uncertain trends in the local and world economy, uneven criteria for urban development and numerous perennial legislative changes. A lot of legal changes have been made in the Republic of Croatia relating to budget planning and defining the sources of financing of cities, moreover, the Personal Income Tax Act has been amended six times in the period from 2014 to 2019, and the Act on the Financing of Local and Regional Self-Government Units has been amended several times, with a new law on local taxes being introduced in 2018. The reasons for numerous legal changes are twofold and partially stem from the adjustment to the relief of the Croatian economy, and partially from the state's efforts to further relieve the tax burden on labour and income taxation. These changes reflected on, and significantly affected, the fiscal capacity of the revenues of large cities. Recommendations are aimed at greater fiscal autonomy of large cities and are aimed at further implementation of fiscal decentralization, especially in the area related to tax revenues.
\end{abstract}

\section{Keywords:}

Large cities, tax revenues, own revenue, fiscal capacity 


\section{Introduction}

The territorial and regional organization of modern states is based on the principles of decentralization, which implies, according to Tanza (1995), the allocation and distribution of powers to lower sub national units. Powers are defined by the Constitution or special laws within clearly defined criteria that enables the collection of taxes, but also independent planning of public spending. Sub national units in the formative sense and from the point of view of territorial organization include the existence of several levels of government from central, regional to local authorities and, as Šinković (2019: 223) argues, represent a standard solution and a common pattern of many modern states.

The most important changes in fiscal decentralization, as explained by Šimović, Rogić Lugarić (2006) are focused on two significant processes, namely: a) more independent position of local and regional units (administrative and financial) and b) (partial) decentralization of management and financing in certain activities: education, health, social welfare and firefighting. Rašić Bakarić, Šimović and Vizek (2014) state in their research paper that a large problem of local selfgovernment units is stated in limited fiscal autonomy. Namely, the local government is generally not able to determine changes in the rates and bases of local taxes, just like the segment of common taxes which are shared with the central government. Furthermore, Jurlina Alibegović (2018) concludes by an empirical study of the tax autonomy of Croatian cities that a small number of cities can, without the help of the central government, meet the existing level of public services to residents and entrepreneurs, and to manage its own development. However, in accordance with the problems of this paper, Bajo and Jurlina Alibegović (2008: 75) point out that local units acquire revenues from their own and common taxes, assistance from the county and state budget, non-tax revenues and borrowing, but later add the category of capital revenues (2008: 86). The paper analyses a five-year period from 2014 to 2018 in order to minimize the impact of fiscal and tax changes. Financial data for all cities in the Republic of Croatia were used, with large cities singled out for the purposes of analysis and determination of fiscal capacity.

\section{Business Analysis of Large Cities in the Republic of Croatia}

According to the Act on Local and Regional Self-Government, large cities in the Republic of Croatia are considered to be local self-government units which are also economic, financial, cultural, health, transport and scientific centres of development of the wider environment and have more than 35,000 inhabitants. In addition to the responsibility for normal activities, they are entrusted with additional activities such as maintenance of public roads, issuance of construction and location permits, other acts related to construction, and the implementation of spatial planning documents. According to the data from the 2011 census, there are $17^{1}$ large cities in the Republic of Croatia (out of a total of 128 cities, including the City of Zagreb), but over 1.8 million people live in them, i.e. over $43 \%$ of the total population of the Republic of Croatia. These are cities that lead in terms of the value of their assets, but also in terms of the value and diversity of collected revenues.

\footnotetext{
${ }^{1}$ According to the estimates of the Central Bureau of Statistics, the City of Vinkovci has a smaller number of inhabitants than the legal minimum since 2016, but it will be kept on the list of large cities until the next official census (https://www.dzs.hr/Hrv/publication/StatisticsInLine.htm - cities in statistics, accessed: 24/7/2020)
} 
Total revenue of cities in the Republic of Croatia consist of operating revenues and revenues from the sale of non-financial assets. Total revenue of cities in 2018 amounted to 17.9 billion HRK, and operating revenues accounted for $97.6 \%$ of total revenues. Tax revenues represent the most generous revenue of cities, and it, depending on the observed year, varies between $57.7 \%$ and $63.4 \%$ of operating revenues of all cities (Table 1). There is also a significant nominal growth in tax revenues, which amounted to 8.6 billion HRK in 2015, and cities ended year 2018 with over 11 billion HRK in tax revenues. The second most significant operating revenues are revenues from stamp duties and administrative fees, fees according to special regulations and fees, which on average make up almost $20 \%$ of operating revenues, and in $2018,3.2$ billion HRK of revenue was generated on that basis, of which 2.7 billion HRK on the basis of utility taxes and fees. Grant and property revenue amounted to almost 3 billion HRK during the same year.

Table 1 Structure of operating revenues of cities in the Republic of Croatia in the period from 2014 to 2018 (in 000 HRK)

\begin{tabular}{|c|c|c|c|c|c|}
\hline Revenue name & 2014 & 2015 & 2016 & 2017 & 2018 \\
\hline Tax revenue & $9,473,767$ & $8,590,430$ & $9,178,703$ & $8,766,169$ & $11,075,750$ \\
\hline $\begin{array}{l}\text { Aid from abroad (deeds of } \\
\text { donation) and from entities within } \\
\text { the general budget }\end{array}$ & $1,223,014$ & $1,440,335$ & $1,539,680$ & $1,911,685$ & $1,636,643$ \\
\hline Property revenue & $1,244,578$ & $1,267,214$ & $1,221,079$ & $1,245,625$ & $1,346,978$ \\
\hline Fee and commission revenue* & $2,808,540$ & $2,916,075$ & $2,998,528$ & $3,070,392$ & $3,148,258$ \\
\hline $\begin{array}{l}\text { Revenue from sales of products } \\
\text { and goods and services provided } \\
\text { and revenues from donations }\end{array}$ & 104,719 & 75,864 & 89,763 & 74,182 & 92,262 \\
\hline $\begin{array}{l}\text { Revenue from the competent } \\
\text { budget }\end{array}$ & 1,197 & 0 & 0 & 0 & 0 \\
\hline $\begin{array}{l}\text { Fines, administrative measures } \\
\text { and other revenues }\end{array}$ & 133,053 & 145,796 & 116,743 & 120,490 & 161,592 \\
\hline Total operating revenues & $14,988,867$ & $14,435,713$ & $15,144,496$ & $15,188,542$ & $17,461,484$ \\
\hline \multicolumn{6}{|l|}{ Share in $\%$} \\
\hline Tax income & $63.2 \%$ & $59.5 \%$ & $60.6 \%$ & $57.7 \%$ & $63.4 \%$ \\
\hline $\begin{array}{l}\text { Aid from abroad (deeds of } \\
\text { donation) and from entities within } \\
\text { the general budget }\end{array}$ & $8.2 \%$ & $10.0 \%$ & $10.2 \%$ & $12.6 \%$ & $9.4 \%$ \\
\hline Property income & $8.3 \%$ & $8.8 \%$ & $8.1 \%$ & $8.2 \%$ & $7.7 \%$ \\
\hline Fee and commission income ${ }^{*}$ & $18.7 \%$ & $20.2 \%$ & $19.8 \%$ & $20.2 \%$ & $18.0 \%$ \\
\hline $\begin{array}{l}\text { Income from sales of products and } \\
\text { goods and services provided and }\end{array}$ & $0.7 \%$ & $0.5 \%$ & $0.6 \%$ & $0.5 \%$ & $0.5 \%$ \\
\hline
\end{tabular}




\begin{tabular}{|l|r|r|r|r|r|}
\hline revenues from donations & & & & & \\
\hline Income from the competent budget & $0.0 \%$ & $0.0 \%$ & $0.0 \%$ & $0.0 \%$ & $0.0 \%$ \\
\hline $\begin{array}{l}\text { Fines, administrative measures } \\
\text { and other revenues }\end{array}$ & $0.9 \%$ & $1.0 \%$ & $0.8 \%$ & $0.8 \%$ & $0.9 \%$ \\
\hline \multicolumn{1}{|c|}{ Total operating income } & $100.0 \%$ & $100.0 \%$ & $100.0 \%$ & $100.0 \%$ & $100.0 \%$ \\
\hline
\end{tabular}

Source: Author's representation based on data from the Ministry of Finance of the Republic of Croatia, https://mfin.gov.hr/istaknute-teme/lokalna-samouprava/financijski-izviestaii-jlp-r-s/203

(accessed:

24/7/2020), *Revenues from stamp duties and administrative fees, fees under special regulations and fees

Since there is no unambiguous definition of own operating revenue, this paper discusses several aspects that have included or excluded certain revenue from this category. Revenues from the sale of non-financial assets such as revenues from the sale of land, apartments or business premises are excluded, as they do not form part of operating revenues. In addition, one of the key aspects of including a revenue in one's own business revenue is the autonomy of decisionmaking during the introduction and in determining the amount of the obligation paid by citizens or companies. The impact of cities on the level of a particular type of operating revenue currently depends primarily on legislative provisions. Cities have the least autonomy in tax revenues. Namely, the amount of income tax and real estate transfer tax is determined by the state, and cities are left with the possibility of introducing surtax on income tax in strictly defined ranges, in accordance with the Act on the Financing of Local and Regional Self-Government Units (Official Gazette 127/2017). Cities are also left with the possibility of introducing a consumption tax of up to $3 \%$ and a tax on holiday homes in the amount of 5 to $15 \mathrm{HRK} / \mathrm{m}^{2}$. The tax on the use of public areas is the only tax for which cities have complete freedom related to determining the amount, manner and conditions of payment.

It is important to point out that the state manages the collection of key tax revenues for cities (taxes and surtaxes on income and real estate sales taxes), which further reduces the impact of cities on the total amount of these taxes collected and that cities ultimately share income tax with the county in whose territory they are located. Due to the above stated reasons, tax revenues are not treated in this paper as cities' own revenues. Grant revenues and donation revenues are usually strictly earmarked funds, with very high volatility from year to year, and the sources of these funds are managed by other levels of government or various other entities, so they are also excluded from the category of own revenues. It is similar with the revenues from the competent budget, where since 2015 there has been no revenue for cities. Additionally, the category of other revenues is not included due to its diversity ${ }^{1}$ and unpredictability, because it is all revenue that is not classified in any of the previous categories.

Own operating revenues therefore include property revenues (account $64^{2}$ ), revenues from stamp duties and administrative fees, fees under special regulations and fees (account 65), revenues from the product sales and services provided (account 661), and penalties and administrative measures (account 681 ), and cities in the Republic of Croatia generated 4.6 billion HRK in 2018 on these bases, i.e. $26.3 \%$ of total operating revenues. The share of large cities' own revenues in

\footnotetext{
${ }^{2}$ Account from accounting plan
} 
their operating revenues is shown in Chart 1 . Namely, the stated share ranged from $18.8 \%$ for the City of Slavonski Brod to a high $52.6 \%$ for the City of Dubrovnik. It is important to note that in the upper half of the presented cities are mostly cities from the Adriatic coast and that all have a share of their own operating revenues in total operating revenues above the average of $29 \%$.

Figure 1 Share of own revenues in the operating revenues of large cities in 2018

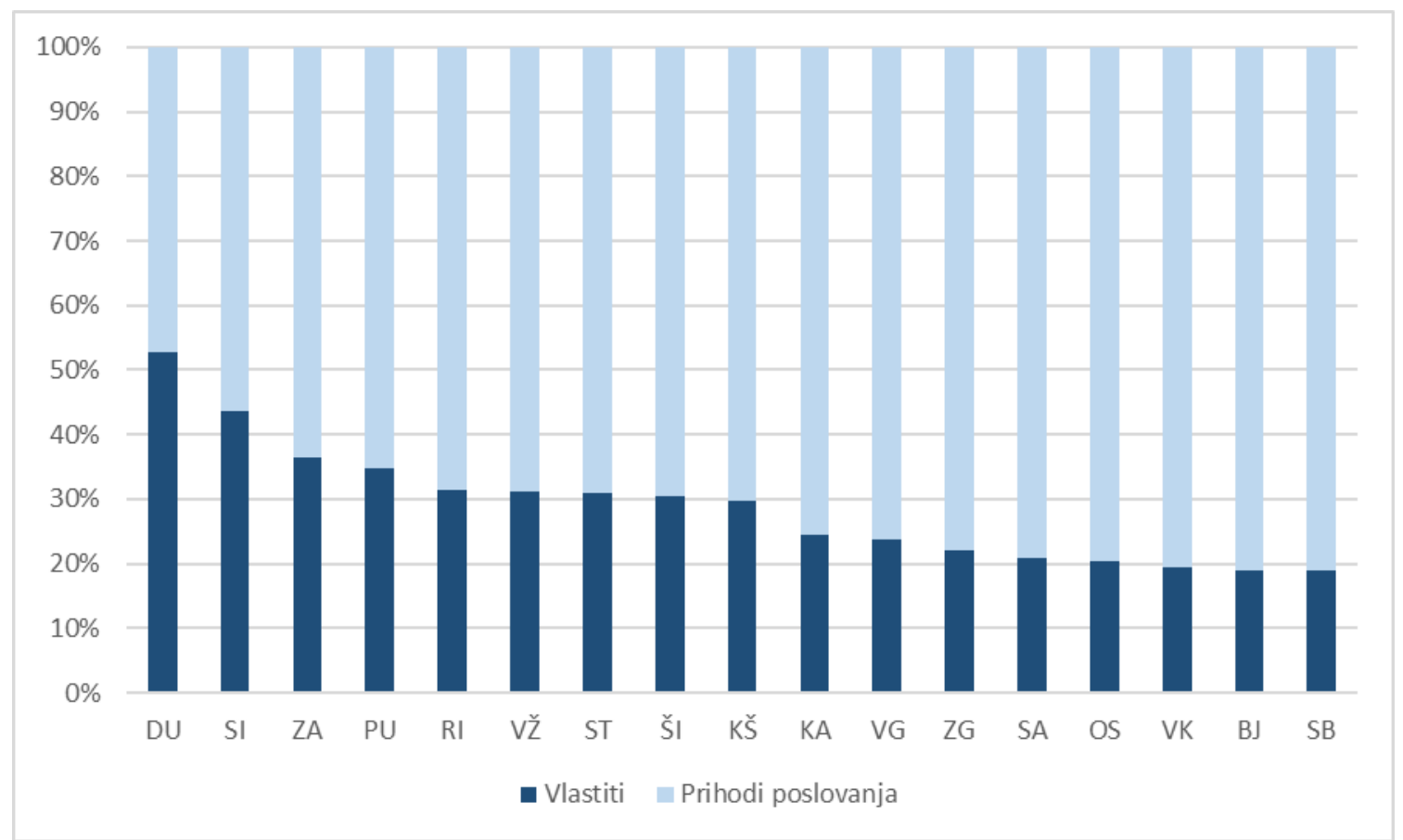

Source: Author's representation based on data from the Ministry of Finance of the Republic of Croatia, https://mfin.gov.hr/istaknute-teme/lokalna-samouprava/financijski-izviestaji-ilp-r-s/203 (accessed:

24/7/2020)

A more detailed analysis of own revenues of only segments of large city, and trends during the analysis of the covered period is shown in Table 2. Revenues from leasing and renting assets are financially the most significant segment of revenues from non-financial assets of large cities, while revenues from non-financial assets make up the majority of total property revenues. This is a very stable revenue of large cities. Large cities record continuous growth (over 13\% in the observed period) of revenues from utility charges and fees, and revenues from fees and commissions account for two thirds of total own operating revenues.

Table 2 The structure of own revenues of large cities in the period from 2014 to 2018

\begin{tabular}{|c|l|l|l|l|l|}
\hline Revenue name & \multicolumn{1}{|c|}{$\mathbf{2 0 1 4}$} & $\mathbf{2 0 1 5}$ & $\mathbf{2 0 1 6}$ & $\mathbf{2 0 1 7}$ & \multicolumn{1}{|c|}{$\mathbf{2 0 1 8}$} \\
\hline Property revenue & 918,473 & 906,171 & 892,854 & 918,936 & 994,834 \\
\hline $\begin{array}{r}\text { Leasing and renting of } \\
\text { assets revenue }\end{array}$ & 398,165 & 402,363 & 423,466 & 434,510 & 433,153 \\
\hline
\end{tabular}




\begin{tabular}{|c|c|c|c|c|c|}
\hline Fee and commission revenue* & $1,866,186$ & $1,905,300$ & $1,964,868$ & $2,034,586$ & $2,069,562$ \\
\hline Utility charges and fees & $1,575,392$ & $1,634,180$ & $1,671,724$ & $1,734,603$ & $1,781,508$ \\
\hline $\begin{array}{l}\text { Revenue from sales of products } \\
\text { and goods and services provided }\end{array}$ & 10,279 & 5,302 & 5,885 & 5,412 & 9,154 \\
\hline $\begin{array}{l}\text { Fines and administrative } \\
\text { measures }\end{array}$ & 29,800 & 27,611 & 33,672 & 30,225 & 45,951 \\
\hline Total & $2,824,738$ & $2,844,383$ & $2,897,279$ & $2,989,159$ & $3,119,501$ \\
\hline \multicolumn{6}{|l|}{ Share in \% } \\
\hline Property revenue & $32.52 \%$ & $31.86 \%$ & $30.82 \%$ & $30.74 \%$ & $31.89 \%$ \\
\hline $\begin{array}{r}\text { Leasing and renting of } \\
\text { assets revenue }\end{array}$ & $14.10 \%$ & $14.15 \%$ & $14.62 \%$ & $14.54 \%$ & $13.89 \%$ \\
\hline Fee and commission revenue* & $66.07 \%$ & $66.98 \%$ & $67.82 \%$ & $68.07 \%$ & $66.34 \%$ \\
\hline Utility charges and fees & $55.77 \%$ & $57.45 \%$ & $57.70 \%$ & $58.03 \%$ & $57.11 \%$ \\
\hline $\begin{array}{l}\text { Revenue from sales of products } \\
\text { and goods and services provided }\end{array}$ & $0.36 \%$ & $0.19 \%$ & $0.20 \%$ & $0.18 \%$ & $0.29 \%$ \\
\hline $\begin{array}{l}\text { Fines and administrative } \\
\text { measures }\end{array}$ & $1.05 \%$ & $0.97 \%$ & $1.16 \%$ & $1.01 \%$ & $1.47 \%$ \\
\hline
\end{tabular}

Source: Author's representation based on data from the Ministry of Finance of the Republic of Croatia, https://mfin.gov.hr/istaknute-teme/lokalna-samouprava/financijski-izvjestaji-jlp-r-s/203 (accessed: 24/7/2020)

The remaining own revenues, which consist of sales revenues and fines and legal measures, make up an almost negligible part of the revenues of large cities. The total own revenues of all cities in the Republic of Croatia, as already pointed out, amounted to 4.6 billion HRK, of which large cities generated 3.1 billion HRK, and all other cities 1.5 billion HRK (Table 3). The City of Zagreb generated higher own revenue than the remaining 111 cities on its own, as its own revenue amounted to 1.6 billion HRK. Large own revenues were generated by all large cities located on the Adriatic coast, especially Split (252 million HRK), Rijeka (223 million HRK) and Dubrovnik, which ranks only 12 th in terms of population, but generates over 258 million HRK in own revenues.

Table 3 Comparison of the population, tax and own revenues of large cities in 2018

\begin{tabular}{|l|r|r|r|r|}
\hline \multirow{2}{*}{2018} & \multirow{2}{*}{20} & \multicolumn{2}{|c|}{ In 000 HRK } & \multicolumn{1}{c|}{ In \% } \\
\cline { 3 - 5 } & Population* & \multicolumn{1}{c|}{ Tax } & \multicolumn{1}{c|}{ Own } & \multicolumn{1}{c|}{ Ratio } \\
\hline Zagreb & 806,341 & $5,394,842$ & $1,592,220$ & 0.295 \\
\hline Split & 170,419 & 492,878 & 252,192 & 0.512 \\
\hline
\end{tabular}




\begin{tabular}{|l|r|r|r|r|}
\hline Rijeka & 117,415 & 370,054 & 223,244 & 0.603 \\
\hline Osijek & 101,911 & 256,774 & 80,221 & 0.312 \\
\hline Zadar & 75,194 & 192,077 & 132,104 & 0.688 \\
\hline Velika Gorica & 62,497 & 167,299 & 62,215 & 0.372 \\
\hline Pula & 56,388 & 163,408 & 100,767 & 0.617 \\
\hline Slavonski Brod & 53,614 & 114,211 & 33,749 & 0.296 \\
\hline Karlovac & 51,447 & 120,188 & 49,454 & 0.411 \\
\hline Varaždin & 45,989 & 137,950 & 72,444 & 0.525 \\
\hline Šibenik & 44,539 & 100,348 & 57,146 & 0.569 \\
\hline Dubrovnik & 44,376 & 180,140 & 258,384 & 1.434 \\
\hline Sisak & 42,844 & 81,030 & 80,229 & 0.990 \\
\hline Kaštela & 40,653 & 89,768 & 40,260 & 0.448 \\
\hline Bjelovar & 38,250 & 77,969 & 23,979 & 0.308 \\
\hline Samobor & 37,666 & 125,374 & 39,749 & 0.317 \\
\hline Vinkovci & 33,920 & 68,061 & 21,144 & 0.311 \\
\hline Large cities in total & $\mathbf{1 , 8 2 3 , 4 6 3}$ & $\mathbf{8 , 1 3 2 , 3 7 2}$ & $\mathbf{3 , 1 1 9 , 5 0 1}$ & $\mathbf{0 . 3 8 4}$ \\
\hline Rest of the cities & $\mathbf{1 , 0 9 8 , 5 2 6}$ & $\mathbf{2 , 9 4 3 , 3 7 9}$ & $\mathbf{1 , 4 7 2 , 7 9 5}$ & $\mathbf{0 . 5 0 0}$ \\
\hline Total amount of cities in the & $\mathbf{2 , 9 2 1 , 9 8 9}$ & $\mathbf{1 1 , 0 7 5 , 7 5 0}$ & $\mathbf{4 , 5 9 2 , 2 9 6}$ & $\mathbf{0 . 4 1 5}$ \\
\hline Republic of Croatia & & & & \\
\hline Source: Authors & & & & \\
\hline
\end{tabular}

Source: Author's representation based on data from the Ministry of Finance of the Republic of Croatia, https://mfin.gov.hr/istaknute-teme/lokalna-samouprava/financijski-izvjestaji-jlp-r-s/203 (accessed: 24/7/2020)

Due to the amount of its own revenue, the City of Dubrovnik leads the ranking of cities when it comes to the ratio of own and tax revenues of 1.434 , while at the bottom of the list is the City of Zagreb with a ratio of only 0.295 (high level of tax revenues). It is interesting to compare the cities of Sisak and Kaštela, which have a similar population (the difference is about 2,200 inhabitants), but significantly different results. Namely, the City of Kaštela has a $10 \%$ higher tax revenue, but half its own operating income.

Table 4 Movement of own revenues of large cities per capita in 2014 and 2018, sorted by population in 2018

\begin{tabular}{|l|c|c|c|c|r|}
\hline \multirow{2}{*}{ Name of the city } & \multicolumn{2}{|c|}{ Estimated population* } & \multicolumn{3}{c|}{ Own revenue per capita } \\
\cline { 2 - 6 } & $\mathbf{2 0 1 4}$ & $\mathbf{2 0 1 8}$ & $\mathbf{2 0 1 4}$ & $\mathbf{2 0 1 8}$ & \multicolumn{1}{c|}{ Change } \\
\hline Zagreb & 799,999 & 806,341 & $1,755.4$ & $1,974.6$ & 219.2 \\
\hline
\end{tabular}




\begin{tabular}{|c|c|c|c|c|c|}
\hline Split & 174,333 & 170,419 & $1,464.9$ & $1,479.8$ & 14.9 \\
\hline Rijeka & 123,725 & 117,415 & $1,910.6$ & $1,901.3$ & -9.3 \\
\hline Osijek & 106,610 & 101,911 & 778.1 & 787.2 & 9.0 \\
\hline Zadar & 75,537 & 75,194 & $1,536.0$ & $1,756.8$ & 220.9 \\
\hline Velika Gorica & 63,984 & 62,497 & 730.0 & 995.5 & 265.5 \\
\hline Pula & 56,676 & 56,388 & $1,709.7$ & $1,787.0$ & 77.4 \\
\hline Slavonski Brod & 57,797 & 53,614 & 511.6 & 629.5 & 117.9 \\
\hline Karlovac & 53,770 & 51,447 & $1,119.5$ & 961.3 & -158.2 \\
\hline Varaždin & 46,476 & 45,989 & $1,511.5$ & $1,575.2$ & 63.7 \\
\hline Šibenik & 45,714 & 44,539 & $1,384.8$ & $1,283.0$ & -101.8 \\
\hline Dubrovnik & 43,400 & 44,376 & $3,967.9$ & $5,822.6$ & $1,854.7$ \\
\hline Sisak & 45,844 & 42,844 & $1,388.2$ & $1,872.6$ & 484.4 \\
\hline Kaštela & 40,501 & 40,653 & 998.1 & 990.3 & -7.8 \\
\hline Bjelovar & 39,551 & 38,250 & 683.5 & 626.9 & -56.5 \\
\hline Samobor & 37,801 & 37,666 & 957.2 & $1,055.3$ & 98.1 \\
\hline Vinkovci & 35,470 & 33,920 & 656.4 & 623.3 & -33.0 \\
\hline Large cities in total & $1,847,188$ & $1,823,463$ & $1,529.2$ & $1,710.8$ & 181.5 \\
\hline Rest of the cities & $1,153,523$ & $1,098,526$ & $1,121.2$ & $1,340.7$ & 219.5 \\
\hline $\begin{array}{l}\text { Total amount of cities } \\
\text { in the Republic of } \\
\text { Croatia }\end{array}$ & $3,000,711$ & $2,921,989$ & $1,372.4$ & $1,571.6$ & 199.3 \\
\hline
\end{tabular}

Source: Author's representation based on data from the Ministry of Finance of the Republic of Croatia, https://mfin.gov.hr/istaknute-teme/lokalna-samouprava/financijski-izvjestaji-jlp-r-s/203

(accessed: 24/7/2020)

There is a noticeable trend of growth of own operating income per capita. Namely, in the observed period there was a decrease in the number of population in all large cities except in the cities of Zagreb and Kaštela, but there was also a decrease in own revenues in 8 out of 17 large cities. In most of them, these changes have resulted in a decrease in own per capita income. The average own income per capita in all cities of the Republic of Croatia amounted to 1,571.6 HRK, and 10 large cities had an average lower than the national average (Table 4). All other cities achieved a lower average and it amounted to 1,340.7 HRK.

\section{Conclusion}

In the Republic of Croatia during the observed period, the ratio of own and tax revenues of large cities ranged from 0.3 to 1.4. Furthermore, cities such as Zagreb have a low ratio because they have extremely high tax revenues, while cities in Slavonia have a low ratio due to low levels of 
their own revenues. Cities from the Adriatic coast have high ratios, renting their property at higher prices, having higher revenues from the communal contribution due to higher construction, and partly burdening citizens and entrepreneurs more with the communal fee. In order for cities to increase their own revenues, it is necessary to leave the management of the state property (apartments, business premises, etc.) to cities, thus increasing the efficiency of these assets, increasing revenues and reducing their dependence on income tax. Also, cities need greater fiscal autonomy, i.e. if there is a possibility of reducing the surtax rate, there should be a possibility of reduction the income tax rate. The stated can represent a "fiscal tool" for cities through which they could have a significant impact on economic growth in a given area within the framework of fiscal management. The possibility of introducing a real estate tax as an additional tax source, which would replace the reduced income from the targeted reduction of the income tax and thus relieve the dependence on the central government, is also considered significant.

\section{$4 \quad$ References}

Bajo, A. i Jurlina Alibegović, D. (2008). Javne financije lokalnih jedinica vlasti. Zagreb: Školska knjiga, Ekonomski institut i Institut za javne financije.

Državni zavod za statistiku - gradovi u statistici.

Jurlina Alibegović, D. (2018). Porezna autonomija gradova u Hrvatskoj u razdoblju 2002.-2016. Zagreb: Ekonomski institut.

Koprić, I. „Decentralizacija i dobro upravljanje gradovima“, Hrvatska i komparativna javna uprava, Vol.9, No. 1, pp 69-77, 2009.

Ministarstvo financija - financijski izvještaji JLP(R)S.

Rašić Bakarić, I., Šimović. H., Vizek, M. „Ekonomska uspješnost gradova u Hrvatskoj - statistička analiza“, Ekonomski pregled, Vol. 65, No. 2, pp 115-138, 2014.

Rogić Lugarić, T. (2012). Financiranje velikih gradova. Zagreb: Pravni fakultet sveučilišta u Zagrebu, Studijski centar za javnu upravu i javne financije.

Rogić Lugarić, T. „Financijski aspekti položaja velikih gradova“, Hrvatska i komparativna javna uprava, Vol. 10, No. 3, pp 683-708, 2010

Šimović, J., Rogić Lugarić, T. „Financiranje javnih potreba u velikim gradovima: Iskustva grada Zagreba“, Zbornik pravnog fakulteta u Zagrebu, Vol. 56, No. 6, pp 1847-1912, 2006.

Šinković, Z. (2019). Financiranje jedinica lokalne i područne (regionalne) samouprave. Split: Zbornik radova Pravnog fakulteta u Splitu, pp 223-250.

Tanzi, V. (1996) "Fiscal Federalism and Decentralization: A review of some Efficiency and Macroeconomics Aspects," u Annual World bank conference on development economics, pp. $295-315$. The international bank for reconstruction and development. Vol. 9, No. 1 ., pp 69-77, 2009.

Zakon o financiranju jedinica lokalne i područne (regionalne) samouprave (Narodne novine 127/2017). 
Zakon o lokalnoj i područnoj (regionalnoj) samoupravi (Narodne novine br. , 33/01, 60/01, 129/05, 109/07, 125/08, 36/09, 36/09, 150/11, 144/12, 19/13, 137/15, 123/17, 98/19.

Zakon o lokalnoj i područnoj (regionalnoj) samoupravi (Narodne novine 33/2001, 60/2001, 129/2005, 109/2007, 36/2009, 125/2008, 36/2009, 150/2011, 144/2012, 123/2017, 98/19).

Zakon o porezu na dohodak ("Narodne novine" br. 115/16., 106/18., 121/19., 32/20.).

Zakon o porezu na dohodak (Narodne novine br. 177/04., 73/08., 80/10., 114/11., 22/12., 144/12., 43/13., 120/13., 125/13., 148/13., 83/14., 143/14., 136/15., 115/16.).

Zakon o proračunu (Narodne novine 15/2015) 